\title{
Respon Pertumbuhan dan Hasil Tanaman Tomat (Solanum lycopersicum) Varietas Fortuna pada Perlakuan Kombinasi Pupuk Tunggal dan Beberapa Komposisi Media Tanam
}

\section{Growth and Yield Response of Tomato (Solanum lycopersicum) Fortuna Variety on Combination of Single Fertilizer and Growing Media Compositions}

\author{
Agus Firman Damanik, Titin Setyorini*)
}

\author{
Program Studi Agroteknologi, Fakultas Pertanian, Institut Pertanian Stiper Yogyakarta \\ JI. Nangka II, Krodan, Maguwoharjo, Kec. Depok, Kabupaten Sleman, Daerah Istimewa \\ Yogyakarta 55281 \\ *) Penulis untuk korespodensi E-mail: titin@instiperjogja.ac.id
}

Diajukan: 11 Januari 2021/Diterima: 29 September 2021 /Dipublikasi: 26 November 2021

\begin{abstract}
Tomato productivity depends on the interaction between plant genetic and environmental conditions. The non-superior seed, improper fertilization and unsuitable growing media are the factors that can cause low productivity of tomato. The research aims to determine growth and yield of tomato plants in combination of single fertilizer and composition of different growing media. The research was conducted in the INSTIPER KP-2 field from February to July 2020. Factorial Completely Randomized Design (CRD) was used as experimental design. The first factor was the combination of single fertilizer consisting of four levels, namely PO = Urea: $T S P: K C I$ (2: 2: 2) g.plant ${ }^{-1}$ (control), $P 1$ = Urea: TSP: $K C I$ (3: 1.5: 1.5) g.plant ${ }^{-1}, P 2=$ Urea: $T S P: K C I$ (1.5: 3: 1.5) g.plant ${ }^{-1}, P 3=$ Urea: $T S P: K C l$ (1.5: 1.5: 3) g.plant ${ }^{-1}$. The second factor was the composition of growing media which consists of four levels, namely $\mathrm{MO}=$ Soil (control), M1= Soil + Manure, M2= Soil + Husk Charcoal, M3= Soil + Manure + Husk Charcoal. Analysis of variance (ANOVA) and Duncan's Multiple Range Test (DMRT), both with significance level of $5 \%$, were used to find out whether significant difference among treatment. The results showed that there was no interaction effect between treatment combination of single fertilizers and growing media composition to all observed variables. The combination of single fertilizer had the same effect to all research variables. The composition of growing media significantly increased growth such as plant height, stem diameter, leaf chlorophyll, flowering age, fruit number per plant, total fruit weight per plant, shoot fresh weight, shoot dry weight, and root fresh weight. M3 which is soil, manure and husk charcoal was the best growing media composition.
\end{abstract}

Keywords: tomatoes; fortuna varieties; combination of single fertilizers; growing media

\section{INTISARI}

Hasil tanaman tomat dipengaruhi oleh interaksi antara faktor genetik dan kondisi lingkunganya. Faktor yang dapat menyebabkan produksi tomat masih rendah adalah penggunaan benih tidak unggul, pupuk yang belum optimal dan macam media tanam yang belum tepat. Penelitian ini bertujuan untuk mengetahui respon pertumbuhan dan hasil tanaman tomat dengan perlakuan kombinasi pupuk tunggal dan media tanam. Penelitian telah dilaksanakan di kebun KP-2 INSTIPER pada bulan Februari - Juli 2020 
menggunakan rancangan acak lengkap faktorial. Faktor pertama adalah kombinasi pupuk tunggal yang terdiri dari $\mathrm{P0}=$ Urea $: \mathrm{TSP}: \mathrm{KCl}(2: 2: 2)$ g.tanaman ${ }^{-1}, \mathrm{P} 1=$ Urea : TSP : KCl (3: $1.5: 1.5)$ g.tanaman ${ }^{-1}, \mathrm{P} 2=$ Urea : TSP : KCl $(1.5: 3: 1.5)$ g.tanaman ${ }^{-1}, \mathrm{P} 3$ $=$ Urea : TSP : KCl $(1.5: 1.5: 3)$ g.tanaman-1. Faktor kedua yaitu macam media tanam yang terdiri dari $M 0=$ Tanah, $M 1=$ Tanah + Pupuk kandang, M2 = Tanah + Arang Sekam, M3 = Tanah + Pupuk kandang + Arang Sekam. Data hasil pengamatan dianalisis dengan ANOVA dan DMRT pada jenjang nyata $5 \%$ untuk mengetahui beda nyata antar perlakuan. Multiple Hasil penelitian menunjukkan tidak terjadi interaksi nyata antara perlakuan kombinasi pupuk tunggal dan media tanam terhadap semua variabel yang diamati. Perlakuan kombinasi pupuk tunggal memberikan pengaruh yang sama pada semua variabel penelitian. Macam media tanam memberikan pengaruh berbeda pada variabel tinggi tanaman, diameter batang, klorofil daun, umur berbunga, jumlah buah per tanaman, total bobot buah per tanaman, berat basah tajuk, berat kering tajuk, dan berat basah akar. Perlakuan media tanam terbaik adalah M3 yaitu tanah, pupuk kandang dan arang sekam.

Kata kunci: tomat; varietas fortuna; kombinasi pupuk tunggal; media tanam

\section{PENDAHULUAN}

Hasil tanaman tomat dipengaruhi oleh interaksi antara faktor genetik tanaman dan kondisi lingkunganya. Faktor yang dapat menyebabkan produksi tanaman tomat masih rendah adalah penggunaan benih varietas yang tidak unggul, penggunaan pupuk yang belum optimal dan macam media tanam yang belum tepat. Upaya yang dapat diusahakan untuk menanggulangi turunnya produksi tomat adalah perbaikan teknik budidaya melalui penggunaan varietas unggul sebagai bahan tanam yang didukung oleh kegiatan pemeliharaan (pemupukan) dan media tanam yang tepat.

Varietas tanaman tomat yang ada di pasaran sangat beragam, salah satu varietas tomat unggul adalah Fortuna. Cahyono (2008) berpendapat bahwa tomat varietas Fortuna memiliki ciri sebagai berikut: tanaman subur dan kuat, cepat tumbuh, memiliki ketahanan terhadap penyakit layu fusarium dan verticilium, tipe pertanaman determinate, memiliki percabangan dan daun yang baik, serta ukuran buahnya sedang dan beratnya 50 gram per buah. Oleh karena itu, varietas Fortuna dapat menjadi salah satu alternatif bahan tanam unggul yang dapat dikembangkan oleh petani tomat.

Pemupukan merupakan salah satu kegiatan pemeliharaan yang berperan dalam memberikan nutrisi bagi tanaman. Pupuk dibedakan menjadi pupuk organik (pupuk alami) dan pupuk anorganik (pupuk kimia) berdasarkan asal bahannya. (Hariyadi et al., 2019) menyatakan bahwa pupuk organik berasal dari pelapukan bahan organik seperti kompos dan pupuk kandang. Pupuk anorganik merupakan pupuk yang berasal dari bahan kimia anorganik yang dibuat oleh pabrik. Menurut (Rahhutami and Yahya, 2015) nutrisi yang diberikan pada tanaman melalui pemupukan dapat berupa pupuk anorganik tunggal yaitu pupuk yang hanya terdiri dari satu unsur hara saja. Sebagai contoh pupuk Urea sebagai sumber nitrogen $(\mathrm{N})$, Triple Super Phosphate (TSP) sumber phospor $(\mathrm{P})$, dan Kalium Chlorida $(\mathrm{KCl})$ 
sumber unsur kalium (K). Sebagian besar petani di Indonesia masih menggunakan pupuk tunggal secara terpisah dan tanpa mempertimbangkan keseimbangan komposisi pupuk yang dibutuhkan oleh tanaman. Hal ini menyebabkan tanaman kekurangan nutrisi dan efesiensi pemupukan menjadi rendah (Hariyadi et al., 2019).

Media tanam merupakan tempat bagi akar untuk tumbuh serta menyerap nutrisi, air dan udara yang diperlukan oleh tanaman. (Titiaryanti, Setyorini and Sormin, 2018) menyatakan bahwa pemanfaatan tanah sebagai media tanam secara terus menerus tanpa penambahan bahan organik dapat menyebabkan terjadinya kerusakan struktur tanah. Pemilihan media tanam yang tepat menjadi hal mendasar yang dibutuhkan dalam mengelola tanaman terutama untuk pembentukan sistem perakaran yang sehat dan kuat (Wilkinson et al., 2014). Menurut (Mirseyedhosseini et al., 2017) media tanam harus memiliki karakteristik mendasar yaitu drainase baik, kemampuan mengikat air, kapasitas pertukaran kation yang tepat, bebas dari mikroorganisme yang merugikan tanaman serta terdapat bahan organik. (Wilkinson et al., 2014) menambahkan media tanam yang baik harus memperhatikan sifat fisik yaitu memiliki kemampuan mengikat air, aerasi, porositas dan bulk density (kerapatan massa); sifat kimia antara lain kesuburan, $\mathrm{pH}$, dan kapasitas tukar kation; serta sifat biologi terkait keberadaan mikroorganisme. Penambahan bahan organik seperti pupuk kandang maupun arang sekam pada media tanah dapat memaksimalkan fungsi media tanam bagi pertumbuhan tanaman karena dapat terbentuk media tanam yang gembur dan remah. Menurut (Titiaryanti et al., 2018) media tanam yang gembur dan remah memiliki pori makro, meso dan mikro secara seimbang.

Berdasarkan uraian di atas maka diperlukan penelitian untuk mengetahui kombinasi dosis pupuk tunggal serta media tanam yang paling tepat untuk pertumbuhan dan hasil produksi pada tanaman tomat.

\section{BAHAN DAN METODE}

Penelitian telah dilaksanakan di kebun KP-2 INSTIPER yang terletak di Sleman Yogyakarta pada bulan Februari sampai dengan Juli 2020. Penelitian dilakukan pada saat peralihan musim hujan menuju musim kemarau dengan kondisi suhu dan kelembaban lingkungan yang cukup tinggi yaitu suhu rata-rata $30^{\circ} \mathrm{C}$ dan kelembaban udara 64\%. Bahan yang digunakan adalah benih tomat varietas Fortuna, tanah regosol, pupuk kandang, arang sekam, pupuk N (urea), pupuk $\mathrm{P}$ (TSP), pupuk $\mathrm{K}(\mathrm{KCl})$, dan polibag ukuran $30 \mathrm{~cm} \times$ $30 \mathrm{~cm}$. Peralatan yang digunakan antara lain ember, gembor, cetok, timbangan analitik, jangka sorong, ajir dari tali raffia/bambu, meteran, klorofil meter merek SPAD-502, dan alat tulis.

Rancangan penelitian yang digunakan adalah Rancangan Acak Lengkap dengan dua faktor. Faktor pertama adalah kombinasi pupuk tunggal yang terdiri dari empat aras yaitu P0 = Urea : TSP : KCL (2 : $2: 2$ g.tanaman $\left.{ }^{-1}\right), \mathrm{P} 1=$ Urea : TSP : KCL (3 : 
$1.5: 1.5$ g.tanaman $\left.{ }^{-1}\right), P 2=$ Urea $: \mathrm{TSP}: \mathrm{KCL}$ $\left(1.5: 3: 1.5\right.$ g.tanaman $\left.^{-1}\right), \mathrm{P} 3=$ Urea $:$ TSP : KCL (1.5: 1.5 : 3 g.tanaman $\left.{ }^{-1}\right)$. Pupuk diaplikasi setiap satu minggu sekali sesuai perlakuan dengan cara ditugal sampai menjelang panen pertama. Faktor kedua yaitu macam media tanam yang terdiri dari empat aras yaitu M0 = Tanah (kontrol), M1 = Tanah + Pupuk Kandang (1:1), M2 = Tanah + Arang Sekam (1:1), M3 = Tanah + Pupuk Kandang + Arang Sekam (1:1:1). Kombinasi perlakuan dari kedua faktor tersebut adalah 16 dan setiap kombinasi perlakuan diulang sebanyak 4 kali.

Penelitian diawali dengan persemaian benih dan persiapan media tanam sesuai dengan perlakuan. Penanaman dilakukan menggunakan bibit tomat dari persemaian yang memiliki tinggi $\pm 5 \mathrm{~cm}$. Pemupukan dilakukan sesuai dengan perlakuan setiap satu minggu sekali mulai tanaman berumur dua minggu setelah tanam sampai dengan menjelang panen yang pertama (dilakukan sebanyak 8 kali). Pemanenan buah tomat dilakukan pada saat tanaman telah memiliki ciri-ciri: kulit buah berwarna kuning kemerahan hingga merah. Pemanenan dilakukan pada saat pagi atau sore hari. Total pemanenan sebanyak 4 kali dengan interval 7 hari sekali.

Variabel yang diamati dalam penelitian adalah tinggi tanaman, diameter batang, klorofil daun (diamati menggunakan alat Chlorophyll meter dengan cara mengambil sampel sebanyak 3 daun yang mewakili setiap tanaman), umur berbunga (ditandai dengan muncul bunga pertama kali untuk setiap tanaman), lama waktu bunga menjadi bakal buah (diwakili oleh dua bunga setiap tanaman), jumlah buah per tanaman, diameter buah per tanaman, total bobot buah per tanaman, rata-rata berat buah per tanaman, berat basah tajuk, berat kering tajuk, berat basah akar, berat kering akar, dan volume akar.

Data yang diperoleh dianalisis dengan ANOVA pada jenjang nyata $5 \%$. Apabila terdapat perbedaan nyata dilanjutkan dengan Uji DMRT (Duncan Multiple Range Test) dengan jenjang nyata $5 \%$.

\section{HASIL DAN PEMBAHASAN}

Hasil penelitian menunjukan bahwa tidak ada interaksi nyata antara perlakuan kombinasi pupuk tunggal dan komposisi media tanam pada semua variabel pengamatan. Hal ini menunjukkan bahwa masing-masing perlakuan memiliki pengaruh yang terpisah terhadap seluruh variabel pertumbuhan dan hasil produksi tanaman tomat.

Tabel 1 menunjukkan bahwa perlakuan kombinasi pupuk tunggal memberikan pengaruh yang sama terhadap semua variabel pengamatan. Pemberian pupuk tunggal dengan kombinasi berbeda tidak mempengaruhi pertumbuhan maupun hasil produksi tanaman tomat. 
Tabel 1. Pengaruh kombinasi pupuk tunggal (Urea, TSP, $\mathrm{KCl}$ )

\begin{tabular}{lrrrr}
\hline \multicolumn{1}{c}{ Variabel } & \multicolumn{1}{c}{$\mathrm{P} 0$} & \multicolumn{1}{c}{$\mathrm{P} 1$} & \multicolumn{1}{c}{$\mathrm{P} 2$} & \multicolumn{1}{c}{$\mathrm{P} 3$} \\
\hline Tinggi Tanaman (cm) & $75.56 \mathrm{p}$ & $65.28 \mathrm{p}$ & $74.19 \mathrm{p}$ & $71.41 \mathrm{p}$ \\
Diameter Batang (cm) & $0.94 \mathrm{p}$ & $0.87 \mathrm{p}$ & $0.92 \mathrm{p}$ & $0.89 \mathrm{p}$ \\
Klorofil Daun (unit) & $46.72 \mathrm{p}$ & $45.13 \mathrm{p}$ & $44.55 \mathrm{p}$ & $41.98 \mathrm{p}$ \\
Umur Berbunga (hari) & $45.50 \mathrm{p}$ & $49.44 \mathrm{p}$ & $47.19 \mathrm{p}$ & $49.00 \mathrm{p}$ \\
Lama Waktu Bunga Menjadi Bakal Buah (hari) & $10.81 \mathrm{p}$ & $10.94 \mathrm{p}$ & $11.38 \mathrm{p}$ & $11.44 \mathrm{p}$ \\
Jumlah Buah per Tanaman & $10.50 \mathrm{p}$ & $9.13 \mathrm{p}$ & $6.56 \mathrm{p}$ & $9.69 \mathrm{p}$ \\
Diameter Buah per Tanaman (cm) & $3.30 \mathrm{p}$ & $3.22 \mathrm{p}$ & $3.57 \mathrm{p}$ & $3.23 \mathrm{p}$ \\
Total Bobot Buah per Tanaman (g) & $218.08 \mathrm{p}$ & $195.34 \mathrm{p}$ & $185.01 \mathrm{p}$ & $194.00 \mathrm{p}$ \\
Rata-Rata Berat Buah per Tanaman (g) & $25.17 \mathrm{p}$ & $27.75 \mathrm{p}$ & $30.83 \mathrm{p}$ & $24.15 \mathrm{p}$ \\
Berat Basah Tajuk (g) & $89.30 \mathrm{p}$ & $77.34 \mathrm{p}$ & $70.61 \mathrm{p}$ & $95.24 \mathrm{p}$ \\
Berat Kering Tajuk (g) & $16.78 \mathrm{p}$ & $13.21 \mathrm{p}$ & $12.26 \mathrm{p}$ & $15.04 \mathrm{p}$ \\
Berat Basah Akar (g) & $18.51 \mathrm{p}$ & $12.10 \mathrm{p}$ & $14.70 \mathrm{p}$ & $16.18 \mathrm{p}$ \\
Berat Kering Akar (g) & $4.77 \mathrm{p}$ & $2.58 \mathrm{p}$ & $3.20 \mathrm{p}$ & $3.24 \mathrm{p}$ \\
Volume Akar (cm $\left.{ }^{3}\right)$ & $18.94 \mathrm{p}$ & $16.19 \mathrm{p}$ & $15.81 \mathrm{p}$ & $18.00 \mathrm{p}$ \\
\hline
\end{tabular}

Keterangan: Angka yang diikuti huruf yang sama dalam baris menunjukkan tidak ada beda nyata berdasarkan uji DMRT pada jenjang 5\%. [P0 = Urea : TSP : KCL $\left(2: 2: 2\right.$ g.tanaman $\left.{ }^{-1}\right)$,

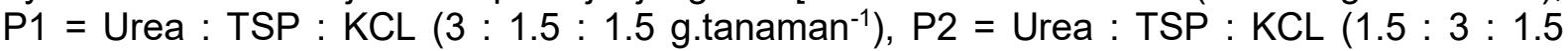
g.tanaman $\left.{ }^{-1}\right), \mathrm{P} 3=$ Urea $:$ TSP $: \mathrm{KCL}\left(1.5: 1.5: 3\right.$ g.tanaman $\left.\left.^{-1}\right)\right]$

Kombinasi perbandingan pupuk dibandingkan dengan unsur Phospor dan tunggal seimbang (P0) cenderung Kalium. Akan tetapi hasil penelitian memberikan hasil paling baik di semua menunjukkan hal yang berbeda. Perlakuan variabel pengamatan meskipun secara $\mathrm{P} 1$ dimana perbandingan pupuk $\mathrm{N}$ dua kali statistik tidak menunjukkan beda nyata. lipat daripada pupuk $P$ dan $K$ belum Macam dan dosis pupuk anjuran pada menunjukkan hasil yang berbeda tanaman tomat banyak disebutkan dalam dibandingkan dengan perlakuan yang berbagai literatur. (Rukmana, 2012) lainnya. Cara pemberian pupuk diduga belum menyampaikan dosis anjuran pemupukan tepat sehingga efisiensi pemupukan menjadi adalah 250 kg.ha-1 Nitrogen, 150 kg.ha-1 tidak optimal. Ketiga pupuk tunggal tersebut Phospor dan $150 \mathrm{~kg} \cdot \mathrm{ha}^{-1}$ Kalium; (Naika et diaplikasikan secara terpisah di hari yang al., 2005) menyatakan bahwa aplikasi pupuk anorganik di daerah tropis berkisar antara 40 - 120 kg.ha-1 Nitrogen, 30 - 90 kg.ha-1 Phospor dan 30 - 90 kg.ha-1 Kalium; (Hamidi, 2019) berpendapat kebutuhan pupuk anorganik untuk tanaman tomat adalah 500 kg.ha-1 ZA (Nitrogen), 170 kg.ha ${ }^{-1}$ SP-36 (Phospor) dan $220 \mathrm{~kg} \cdot \mathrm{ha}^{-1} \mathrm{KCl}$ (Kalium). Dengan demikian, kebutuhan unsur Nitrogen selalu lebih banyak dua sampai tiga kali lipat berbeda dengan cara ditugal. (Achmad and Susetyo, 2014) menyarankan bahwa pemberian pupuk tunggal (urea) sebaiknya tidak dicampur dengan pupuk yang lain dan langsung diaplikasikan dengan cara disebar dan ditutup tanah guna mengurangi kehilangan pupuk akibat penguapan. Pupuk tunggal memang tidak diaplikasikan secara bersamaan dalam satu hari, akan tetapi cara tugal dianggap kurang tepat karena pupuk 
yang diberikan kurang merata diserap oleh akar tanaman. Namun hal yang berbeda disarankan oleh (Muyassir and Manfarizah, 2012) yaitu pemberian pupuk $N$ sebaiknya menggunakan teknik tugal dan pupuk $P$ dengan cara sebar pada tanaman terung yang berkerabat dekat dengan tanaman tomat.
Pada perlakuan kedua, hasil penelitian menunjukkan bahwa komposisi media tanam memberikan pengaruh berbeda terhadap variabel pertumbuhan seperti tinggi tanaman, diameter batang, klorofil daun, umur berbunga, berat basah tajuk, berat kering tajuk dan berat basah akar; serta variabel hasil produksi yaitu jumlah buah per tanaman dan total bobot buah per tanaman (Tabel 2).

Tabel 2. Pengaruh komposisi media tanam

\begin{tabular}{lrrrr}
\hline \multicolumn{1}{c}{ Variabel } & \multicolumn{1}{c}{ M0 } & \multicolumn{1}{c}{ M1 } & \multicolumn{1}{c}{ M2 } & \multicolumn{1}{c}{ M3 } \\
\hline Tinggi Tanaman (cm) & $52.69 \mathrm{~b}$ & $81.97 \mathrm{a}$ & $58.22 \mathrm{~b}$ & $93.56 \mathrm{a}$ \\
Diameter Batang (cm) & $0.79 \mathrm{~b}$ & $1.00 \mathrm{a}$ & $0.80 \mathrm{~b}$ & $1.03 \mathrm{a}$ \\
Klorofil Daun (unit) & $42.49 \mathrm{bc}$ & $45.86 \mathrm{ab}$ & $41.34 \mathrm{c}$ & $48.69 \mathrm{a}$ \\
Umur Berbunga (hari) & $52.63 \mathrm{~b}$ & $42.31 \mathrm{a}$ & $55.19 \mathrm{~b}$ & $41.00 \mathrm{a}$ \\
Lama Waktu Bunga Menjadi Bakal Buah & & & & \\
(hari) & $9.13 \mathrm{a}$ & $13.50 \mathrm{a}$ & $9.31 \mathrm{a}$ & $12.63 \mathrm{a}$ \\
Jumlah Buah per Tanaman & $4.69 \mathrm{c}$ & $9.69 \mathrm{ab}$ & $7.19 \mathrm{bc}$ & $14.31 \mathrm{a}$ \\
Diameter Buah per Tanaman (cm) & $3.33 \mathrm{a}$ & $3.28 \mathrm{a}$ & $3.44 \mathrm{a}$ & $3.28 \mathrm{a}$ \\
Total Bobot Buah per Tanaman (g) & $109.38 \mathrm{~b}$ & $190.21 \mathrm{~b}$ & $179.53 \mathrm{~b}$ & $313.32 \mathrm{a}$ \\
Rata-Rata Berat Buah per Tanaman (g) & $26.80 \mathrm{a}$ & $25.86 \mathrm{a}$ & $29.71 \mathrm{a}$ & $25.53 \mathrm{a}$ \\
Berat Basah Tajuk (g) & $61.81 \mathrm{~b}$ & $79.74 \mathrm{~b}$ & $77.24 \mathrm{~b}$ & $113.71 \mathrm{a}$ \\
Berat Kering Tajuk (g) & $9.95 \mathrm{~b}$ & $14.07 \mathrm{~b}$ & $13.76 \mathrm{~b}$ & $19.51 \mathrm{a}$ \\
Berat Basah Akar (g) & $14.14 \mathrm{~b}$ & $13.20 \mathrm{~b}$ & $12.65 \mathrm{~b}$ & $21.51 \mathrm{a}$ \\
Berat Kering Akar (g) & $2.70 \mathrm{a}$ & $3.04 \mathrm{a}$ & $2.83 \mathrm{a}$ & $5.22 \mathrm{a}$ \\
Volume Akar (cm $\left.{ }^{3}\right)$ & $18.31 \mathrm{a}$ & $17.31 \mathrm{a}$ & $11.56 \mathrm{a}$ & $21.75 \mathrm{a}$ \\
\hline
\end{tabular}

Keterangan: Angka yang diikuti huruf yang sama dalam baris menunjukkan tidak ada beda nyata berdasarkan uji DMRT pada jenjang 5\%. [M0 = Tanah, M1 = Tanah + Pupuk Kandang (1:1), M2 = Tanah + Arang Sekam (1:1), M3 = Tanah + Pupuk Kandang + Arang Sekam (1:1:1)]

Komposisi media tanam yang terdiri dari tanah, pupuk kandang dan arang sekam (M3) secara umum memberikan hasil terbaik pada variabel pertumbuhan dan hasil produksi tanaman tomat. Hal ini dapat disebabkan komposisi media tanam tersebut mendekati ideal untuk tanaman tomat. Menurut (Nasrulloh et al., 2016), penambahan bahan organik seperti pupuk kandang dan arang sekam mampu memperbaiki sifat fisik dan kimia tanah yaitu dengan memperbaiki struktur, tekstur dan kandungan unsur hara tanah. Tanah menjadi lebih terstruktur, agregat lebih baik, kandungan unsur hara meningkat dan mampu mengikat air lebih lama sehingga unsur hara akan lebih mudah diserap dan dimanfaatkan oleh akar untuk pertumbuhan tanaman. Menurut (Haryati, 2014), ciri tanah yang teragregasi lebih baik yaitu memiliki tingkat infiltrasi, permeabilitas, ketersediaan air, mudah diolah, aerasi baik, menyediakan 
media respirasi akar dan aktivitas mikroba tanah yang baik.

(Ramdani et al., 2018) menambahkan bahwa pupuk kandang juga dapat memperbaiki sifat biologi tanah. (Kartika et al., 2013) menyampaikan bahwa pupuk kandang sebagai salah satu pupuk organik juga bermanfaat untuk meningkatkan efisiensi penggunaan pupuk kimia sehingga dosis pupuk dan dampak pencemaran lingkungan akibat penggunaan pupuk kimia dapat dikurangi. Selain itu, pupuk organik juga dapat meningkatkan mikroorganisme tanah yang sangat bermanfaat dalam menyediakan unsur hara tanah dan memperbaiki lingkungan. (Totong et al., 2016) menyatakan bahwa penambahan arang sekam pada media tanam memberikan pengaruh terutama terhadap pertumbuhan tanaman tomat. Arang sekam memiliki kandungan unsur $\mathrm{N}$ yang dibutuhkan oleh tanaman untuk pembentukan dan pertumbuhan bagian vegetatif tanaman dan juga berperan penting dalam proses fotosistesis yang akan meningkatkan pertumbuhan tanaman seperti akar, batang dan daun. Selain itu, arang sekam juga merupakan bahan organik yang memiliki unsur $\mathrm{K}$ yang berperan penting bagi tanaman terutama sebagai katalisator berbagai macam enzim (Ramdani et al., 2018).

Komposisi media tanam M3 (tanah, pupuk kandang dan arang sekam) memberikan hasil terbaik pada variabel pertumbuhan tanaman tomat yaitu berat basah tajuk, berat kering tajuk, dan berat basah akar serta variabel hasil berupa total bobot buah per tanaman. Media tanam yang dilengkapi dengan bahan organik seperti pupuk kandang dan arang sekam mampu mendukung efektivitas pemupukan anorganik yang diberikan pada tanaman tomat sehingga dapat meningkatkan pertumbuhan tanaman dan hasil produksi tanaman tomat. Hasil penelitian ini didukung oleh (Bui et al., 2016) yang menyimpulkan bahwa media tanam tanah, pupuk kandang dan arang sekam berpengaruh nyata pada berat segar dan berat kering brangkasan (tajuk) serta berat buah per tanaman. (Fatmawaty et al., 2016) menunjuk-kan hal yang serupa bahwa dengan adanya penambahan arang sekam pada media tanam memberikan pengaruh terbaik pada variabel berat segar tanaman, berat kering tanaman dan bobot buah per tanaman. Hasil penelitian (Ramdani et al., 2018) juga menyimpulkan bahwa media tanam dengan komposisi tanah, pupuk kandang, dan arang sekam menghasilkan bobot buah per tanaman paling tinggi. Nasaruddin dan Rosmawati cit. (Fatmawaty et al., 2016) menyatakan bahwa pemberian pupuk sangat erat kaitannya dengan fase pertumbuhan vegetatif dan generatif tanaman. Nitrogen merupakan unsur hara utama tanaman yang sangat diperlukan untuk pembentukan atau pertumbuhan bagianbagian vegetatif tana-man seperti daun, batang dan akar yang terkait dengan pembentukan tajuk dan akar tanaman. Phospor adalah unsur hara yang dapat mempercepat serta memperkuat pertumbuhan tanaman muda menjadi tanaman dewasa untuk memasuki fase 
generatif. Kalium yaitu unsur hara yang berperan dalam pembentukan protein dan karbohidrat yang terkait dengan pembentukan buah dan secara tidak langsung dapat mempengaruhi bobot buah.

Analisis statistik menunjukkan bahwa komposisi media tanam yang terdiri dari tanah, pupuk kandang dan arang sekam (M3) tidak berbeda nyata dengan komposisi media tanam tanah dan pupuk kandang (M1) pada variabel pertumbuhan seperti tinggi tanaman, diameter batang dan klorofil daun serta variabel umur berbunga dan jumlah buah per tanaman. Hal ini diduga pada fase pertumbuhan awal atau fase vegetatif tanaman, penambahan arang sekam pada media tanam baru dapat memperbaiki sifat fisik tanah seperti porositas dan erasi akan tetapi belum dapat menambah unsur hara karena meskipun arang sekam mengandung unsur hara $\mathrm{N}$ tetapi belum dalam bentuk yang tersedia bagi tanaman. Arang sekam masih berupa bahan organik yang belum terdekomposisi dengan sempurna sehingga perlu waktu lebih lama untuk terdekomposisi oleh mikroorganisme tanah. Berbeda halnya dengan pupuk kandang yang diberikan pada media tanam. Menurut (Ramdani et al., 2018), pupuk kandang lebih mudah terdekomposisi dan mengandung unsur hara yang lebih banyak. Pupuk kandang yang digunakan dalam penelitian ini memiliki kadar C-organik 18\%, C/N Ratio 15, pH 7-8, kadar air $\pm 20 \%$, Nitrogen $1.892 \%$.

Unsur Nitrogen yang terkandung pada pupuk kandang dapat menambah unsur hara yang diserap oleh tanaman selain dari pemupukan anorganik yang diberikan pada tanaman tomat. (Ramdani et al., 2018) menyatakan bahwa pada fase vegetatif pupuk kandang akan menyediakan unsur hara makro terutama Nitrogen yang memiliki peran penting dalam pertumbuhan daun dan batang yang secara langsung dapat juga meningkatkan tinggi tanaman dan diameter batang. Nitrogen juga berperan sangat penting untuk menyusun klorofil yang merupakan organel utama pada proses fotosintesis tanaman. (Afrilandha and Setiawati, 2018) menambahkan bahwa semakin tinggi kandungan Nitrogen yang tersedia oleh tanaman maka kandungan klorofil pada daun semakin tinggi sehingga proses fotosintesis semakin cepat.

Pertumbuhan tanaman yang baik pada fase vegetatif dapat mempengaruhi mulai masuknya fase generatif tanaman yang dicirikan dengan mulai munculnya organ bunga pada tanaman. Hasil penelitian menunjukkan bahwa umur berbunga tanaman juga dipengaruhi oleh komposisi media tanam, dimana umur berbunga tanaman tomat yang ditanam pada media tanam M3 dan M1 lebih cepat daripada perlakuan yang lain. Hal ini diduga komposisi media tanam tersebut memiliki drainase yang lebih baik karena ada tambahan bahan organik berupa pupuk kandang dan arang sekam. Menurut (Syakur, 2012), tanaman tomat yang ditanam pada tanah lempung berpasir yang memiliki drainase baik akan lebih cepat menghasilkan atau berumur genjah. Semakin cepat tanaman memasuki fase generatif maka dapat berdampak pada 
jumlah buah yang terbentuk. Oleh karena itu, pada penelitian ini variabel umur berbunga berkaitan dengan jumlah buah per tanaman. Semakin cepat tanaman berbunga maka buah yang terbentuk tiap tanamannya akan lebih banyak.

Hasil penelitian menunjukkan bahwa variabel lama waktu bunga menjadi bakal buah, diameter buah per tanaman, dan ratarata berat buah per tanaman tidak dipengaruhi oleh perlakuan kombinasi pupuk tunggal maupun komposisi media tanam. Hal ini diduga karena variabel pengamatan tersebut lebih dipengaruhi oleh faktor genetik tanaman. Fase perkembangan bunga menjadi bakal buah dimulai pada saat bunga sudah mekar berwarna kuning (anthesis) kemudian masuk dalam fase penyerbukan dimana bantuan serangga penyerbuk dan kondisi iklim yang menentukan berhasil atau tidaknya terbentuk bakal buah. Diameter buah dan berat buah per tanaman merupakan karakter kuantitatif pada tanaman tomat. Menurut (Sutjahjo et al., 2015), berat

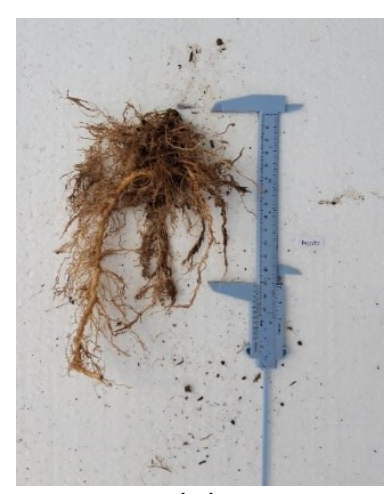

(a)

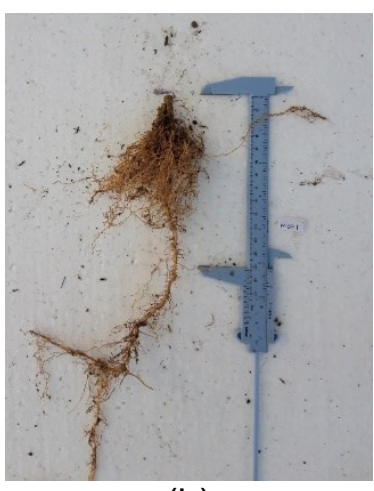

(b)

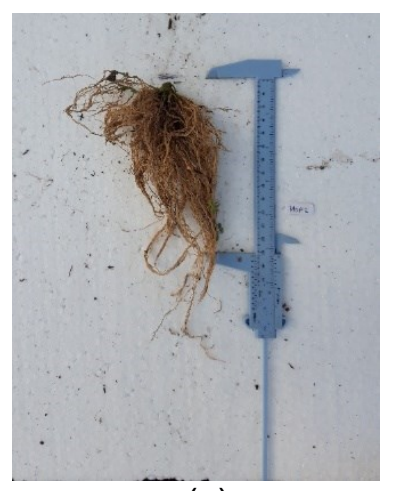

(c)

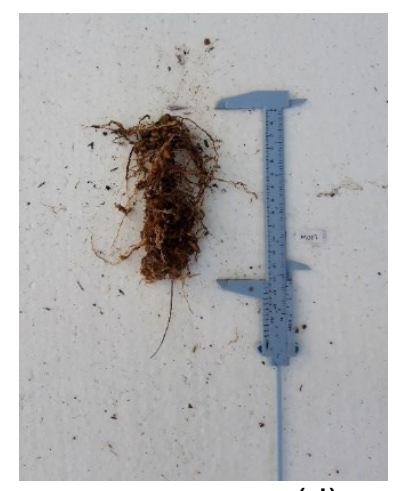

(d)

Gambar 1. Bentuk akar pada media tanah (M0). (a) P0; (b) P1; (c) P2; (d) P3. 


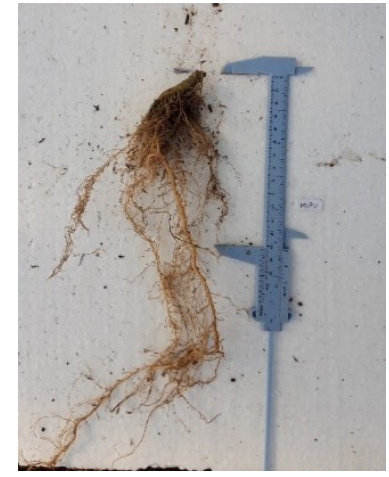

(a)

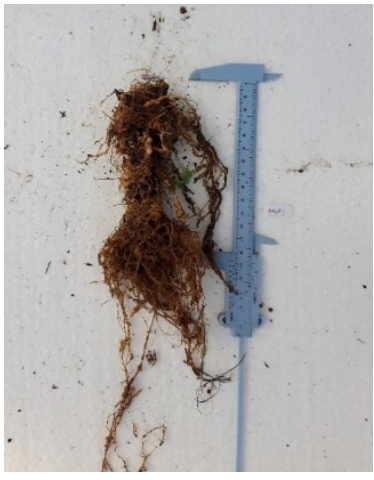

(b)

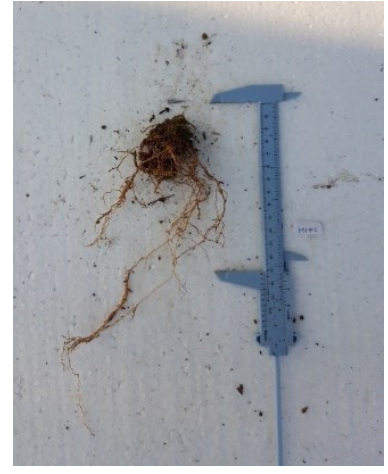

(c)

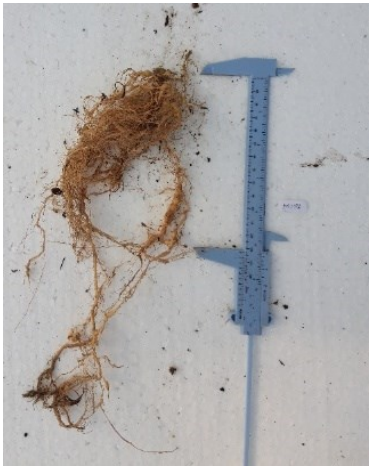

(d)

Gambar 2. Bentuk akar pada media tanah+pupuk kandang (M1). (a) P0; (b) P1; (c) P2; (d)

P3.

Pada Gambar 1 terlihat bahwa memiliki akar lateral atau akar cabang dalam tanaman tomat memiliki jenis perakaran jumlah banyak. Gambar 3 menunjukan tunggang yang bercabang dan akar primer bahwa media tanam tanah+arang sekam yang berukuran kecil seperti batang (M2) memberikan bentuk akar primer yang utamanya. Hasil pengamatan yang dilakukan lebih besar dan jumlah akar lateral atau akar pada Gambar 2 terlihat bahwa media serabut yang lebih banyak dari pada media tanah+pupuk kandang (M1) memberikan tanah+pupuk kandang (M1).

ukuran akar primer yang lebih panjang, serta

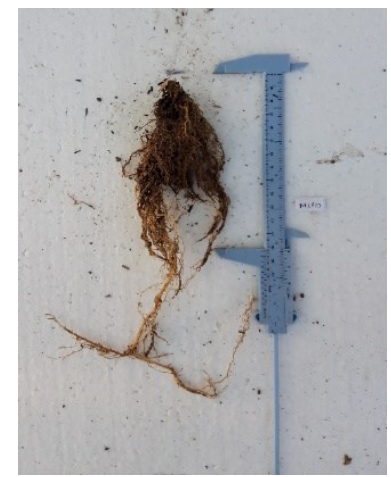

(a)

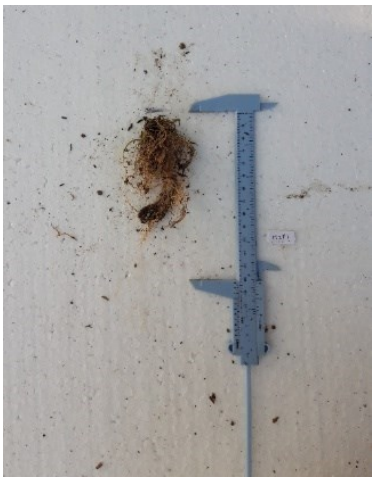

(b)

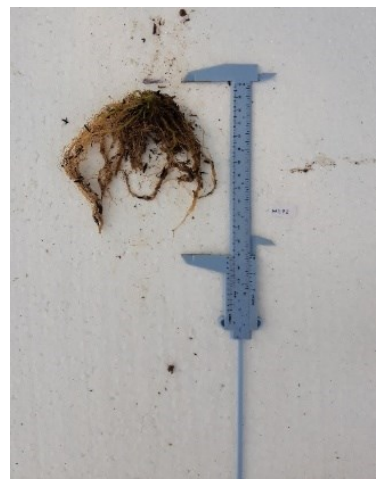

(c)

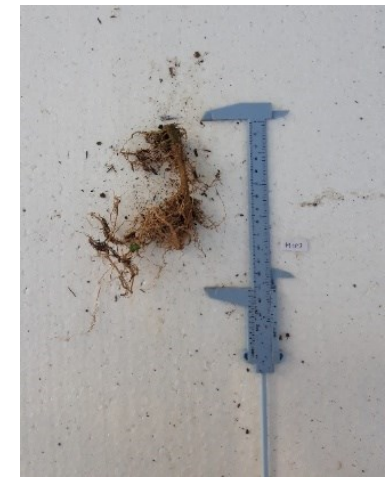

(d)

Gambar 3. Bentuk akar pada media tanah+arang sekam (M2). (a) P0; (b) P1; (c) P2; (d) P3. 


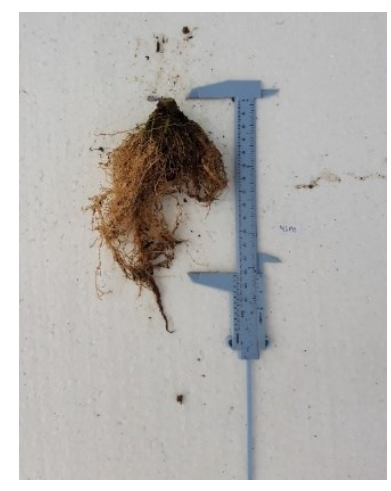

(a)

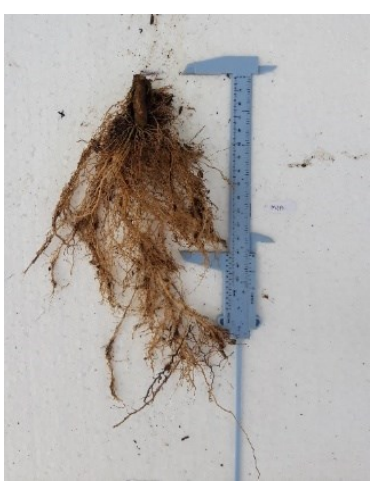

(b)

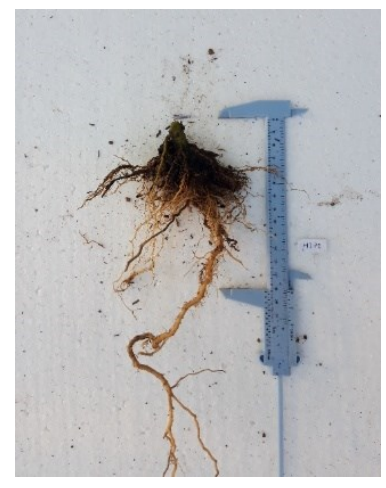

(c)

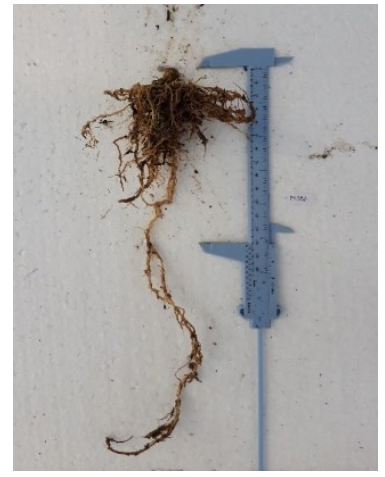

(d)

Gambar 4. Bentuk akar pada media tanah+pupuk kandang+arang sekam (M3). (a) P0; (b)

$$
\text { P1; (c) P2; (d) P3 }
$$

Pada Gambar 4 menunjukan bahwa tananaman tomat memiliki akar tunggang yang bercabang (ramosus) yang berbentuk seperti kerucut dan tumbuh lurus kebawah. Media tanah+pupuk kandang+arang sekam (M3) memberikan perakaran lateral yang lebih tersebar.

\section{KESIMPULAN}

Berdasarkan hasil penelitian dapat disimpulkan bahwa tidak ada interaksi nyata antara perlakuan kombinasi pupuk tunggal dan komposisi media tanam pada tanaman tomat terhadap semua variabel pengamatan. Perlakuan kombinasi pupuk tunggal belum memberikan pengaruh nyata terhadap semua variabel yang diamati. Perlakuan komposisi media tanam memberikan pengaruh berbeda terhadap variabel tinggi tanaman, diameter batang, klorofil daun, umur berbunga, jumlah buah per tanaman, total bobot buah per tanaman, berat basah tajuk, berat kering tajuk, dan berat basah akar. Komposisi media tanam paling baik merupakan campuran dari tanah, pupuk kandang dan arang sekam.

\section{DAFTAR PUSTAKA}

Achmad, S.R. dan I. Susetyo. 2014. Pengaruh proses pencampuran dan cara aplikasi pupuk terhadap kehilangan unsur N. Warta Perkaretan. Riset Perkebunan Nusantara, 33(1): 29. doi: 10.22302/ppk.wp.v33i1.47.

Afrilandha, N. dan M. R. Setiawati, 2018. Pengaruh kombinasi nutrisi anorganik dan pupuk hayati terhadap populasi azotobacter sp, kandungan klorofil, serapan $\mathrm{n}$, dan hasil tanaman tomat pada sistem hidroponik. Agrin. Universitas Jenderal Soedirman, 22(1): 66.

Bui, F., M. A. Lelang, dan R. I. C. O. Taolin. 2016. Pengaruh komposisi media tanam dan ukuran polybag terhadap pertumbuhan dan hasil tomat (Licopercicum escelentum Mill). Savana Cendana. Universitas Timor, 1(1): 1-7. doi: 10.32938/sc.v1i01.1.

Cahyono, B. 2008. Tomat: Usaha Tani \& Penanganan Pascapanen. Yogyakarta: Kanisius.

Fatmawaty, A.A., I. Rohmawati, dan F. N. Marianie. 2016. Respon pemberian berbagai pupuk majemuk dan media tanam terhadap pertumbuhan dan hasil tanaman tomat (Solanum lycopersicum) varietas permata secara hidroponik. Jur. Agroekotek, 8(2): 143153.

doi: 
Hamidi, A. 2019. Budidaya Tanaman Tomat. Available at: http://nad.litbang.pertanian.go.id /ind/index.php/infoteknologi/1093-budidaya-tanamantomat. Diakses 27 Juni 2021.

Hariyadi, B. W. 2019. Effect of dose and time of npk fertilizer application on the growth and yield of tomato plants (Lycopersicum esculentum Mill). Journal of Agricultural Science and Agriculture, 2(2): 101-111.

Haryati, U. 2014. 'Karakteristik Fisik Tanah Kawasan Budidaya Sayuran Dataran Tinggi, Hubungannya dengan Strategi Pengelolaan Lahan. Jurnal Sumberdaya Lahan, 8(2). doi: 10.2018/jsdl.v8i2.6475.

Istianingrum, P. dan Damanhuri. 2016. Keragaman dan heritabilitas sembilan genotip tomat (Lycopersicum esculentum Mill.) pada budidaya organik. Jur. Agroekotek, 8(2): 70-81. doi: 10.33512/J.AGRTEK.V8I2.1480.

Kartika, E., Gani, Z. and Kurniawan, D. 2013. Tanggapan tanaman tomat (Lycopersicum esculentum Mill) terhadap pemberian kombinasi pupuk organik dan pupuk anorganik. Bioplantae, 2(3): 122-131.

Mirseyedhosseini, H., E. Alavipoor, and M. Delshad. 2017. Evaluation of different growth media for tomato seedlings to optimize production and water use. Iran Agricultural Research. Shiraz University, 36(2): 61-70. doi: 10.22099/IAR.2017.4138.

Muyassir dan Manfarizah. 2012. Variasi dosis dan teknik pemupukan npk terhadap sifat kimia tanah, serapan hara serta hasil terung (Solanum melongena L.). Jurnal LENTERA, 12(2).

Naika, S. 2005. Cultivation of tomato production, processing and marketing. Wageningen: Agromisa/CTA.

Nasrulloh, N., T. Mutiarawati, dan W. Sutari. 2016. Pengaruh penambahan arang sekam dan jumlah cabang produksi terhadap pertumbuhan tanaman, hasil dan kualitas buah tomat kultivar doufu hasil sambung batang pada Inceptisol Jatinangor. Kultivasi. Universitas
Padjadjaran, 15(1).

Rahhutami, R. and S. Yahya. 2015. Optimization and effect of $n, p$, and $k$ single fertilizer package rate on two years old immature oil palm (Elaeis guineensis Jacq.). Asian Journal of Applied Sciences, 3(3): 2321-0893.

Ramdani, H., A. Rahayu, dan H. Setiawan. 2018. Peningkatan produksi dan kualitas tomat ceri (Solanum lycopersicum var. cerasiforme) dengan penggunaan berbagai komposisi media tanam dan dosis pupuk SP-36. Jurnal Agronida ISSN, 4(1).

Rukmana, R. 2012.Tomat \& Cherry. Yogyakarta: Kanisius.

Sutjahjo, S. H. 2015. Pendugaan keragaman genetik beberapa karakter pertumbuhan dan hasil pada 30 genotipe tomat lokal. Jurnal Hortikultura. Indonesian Agency For Agricultural Research and Development (IAARD), 25(4): 304. doi: 10.21082/jhort.v25n4.2015.p304-310.

Syakur, A. 2012. Pendekatan satuan panas (heat unit) untuk penentuan fase pertumbuhan dan perkembangan tanaman tomat di dalam rumah tanaman (greenhouse), Agroland: Jurnal IImu-ilmu Pertanian, 19(2).

Titiaryanti, N. M., T. Setyorini, dan S. Y. M. Sormin. 2018. Pertumbuhan Dan Hasil Selada Pada Berbagai Komposisi Media Tanam Dengan Pemberian Urin Kambing. AGROISTA: Jurnal Agroteknologi, 2(1): 20-27.

Totong, O., A. Hadid, dan H. Mas'ud. 2016. Pertumbuhan dan hasil tanaman tomat (Lycopersicum esculentum Mill) pada berbagai media tumbuh dengan interval penyiraman air kelapa yang berbeda. Agrotekbis, 4(6): 693-701.

Wilkinson, K. M. 2014. A Guide to Starting and Operating a Nursery for Native and Traditional Plants Tropical Nursery Manual United States Department of Agriculture. United State Departement of Agriculture. 